International Journal of Engineering Applied Sciences and Technology, 2019

Vol. 4, Issue 3, ISSN No. 2455-2143, Pages 259-265

Published Online July 2019 in IJEAST (http://www.ijeast.com)

IMPACT OF MACROECONOMIC VARIABLES ON FINANCIAL PERFORMANCE OF INDIAN BANKING SECTOR

\author{
Anshu \\ Research Scholar \\ IMSAR, MDU Rohtak, Haryana, India
}

\author{
Dr. Kamlesh Gakhar \\ Professor \\ IMSAR, MDU Rohtak, Haryana, India
}

\begin{abstract}
In India there are different sectors which play the major role of accelerator in the growth of Indian economy. In this study, the area of focus is financial transactions sector specially banking sector which plays a momentous role in the economic growth by regulating and controlling the demand for and supply of money. Interrelationship between macroeconomic variables and financial performance has been an issue of debate amongst economists, policy makers and scholars at all level of the economies whether developed or developing . The Indian banking sector supports the fastest growing economy of the world but it is grappling with multiple challenges. Primary among them is the changing macroeconomic environment. The impact of macroeconomic variables broadly depends on how the different financial performance indicators of banking industry react according to change in macroeconomic variables and how management can help in assessing these variables. This research paper analyzes the relationship between macroeconomic variables and financial performance indicator and highlights the role of management in changing economic scenario in banking sector. The present study is empirical by nature. Descriptive cum exploratory research design has been used in this study. Various statistical tests such as Johansen cointegration test, ARDL, Granger causality test and regression analysis have been used for data analysis.
\end{abstract}

Key words: Indian Banking sector, macroeconomic variables, financial performance and management.

\section{INTRODUCTION OF THE STUDY}

Indian Banking Industry In India currently there are 26 banks working under the public sector, 21 under the private sector and 50 under the foreign sector. Along with this there are 58 regional rural banks, 1,564 urban cooperative banks and 94386 rural cooperative banks. All these banks are working under the central flagship authority of Reserve Bank of India.

Besides these, there are 10 small finance banks and 11 payment banks operating and running their operations to cope up with Indian Banking system. In India these institutions play the role of intermediary authorities by creating and meeting ground for investors and savers through mobilization of financial resources.

The effectiveness of financial institutions is very significant in stimulating the economic development, foreign and domestic investment, and reduction of poverty \& generation of employment (Kyalo, 2002). Banking in India and the financial services complemented rapid growth that has supported the overall expansion of the economy. At the current rate Indian banking industry will be third largest industry in the world by 2025(EIU country data; OECD; IBA data; BCG analysis). The interrelationship between macroeconomic variables and financial performance has been an issue of debate since the pioneering work by Tobin in 1960.

Financial performance of banks has been the key issue amongst economists, policy makers and scholars at all level of the economies whether developed or developing. The downturn in economy due to global crises, banking scams, various insolvencies of business houses and collapse of the stock market have made the macroeconomic environment a key issue of concern while measuring the financial performance of banks (E. Sharma \& M. Mani, 2012)

Indian banks' are contributing significantly in the growth of nation. Banks' credit has been increasing at a rate of 12.64 per cent yearly and reached to Rs 85.511 lakh crore in May, 2018 from Rs 75.91 lakh crore in May, 2017.In FY17-18, total lending of banks reached at a CAGR of 10.94 per cent and total deposits increased with a CAGR of 11.66 per cent. Banking in India and the financial services are rapidly growing and also supporting the overall expansion of economy. 


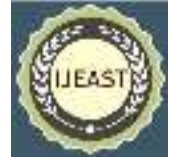

Retail credit of Indian banks is the fourth largest among emerging economies and reached to US\$ 281 billion on 2018 from US\$ 181 billion on 2014. In terms of the market share, the state-owned banks account for $68 \%$, Private sector banks hold $19 \%$ share and foreign banks hold $7 \%$ share in the Indian banking. Rural and Urban Cooperative banks have $3 \%$ share in the Indian banking industry. Local area banks holds around $2 \%$ of the market share as per RBI data source.

Figure 1.1

Market share of banks in India

Source: RBI

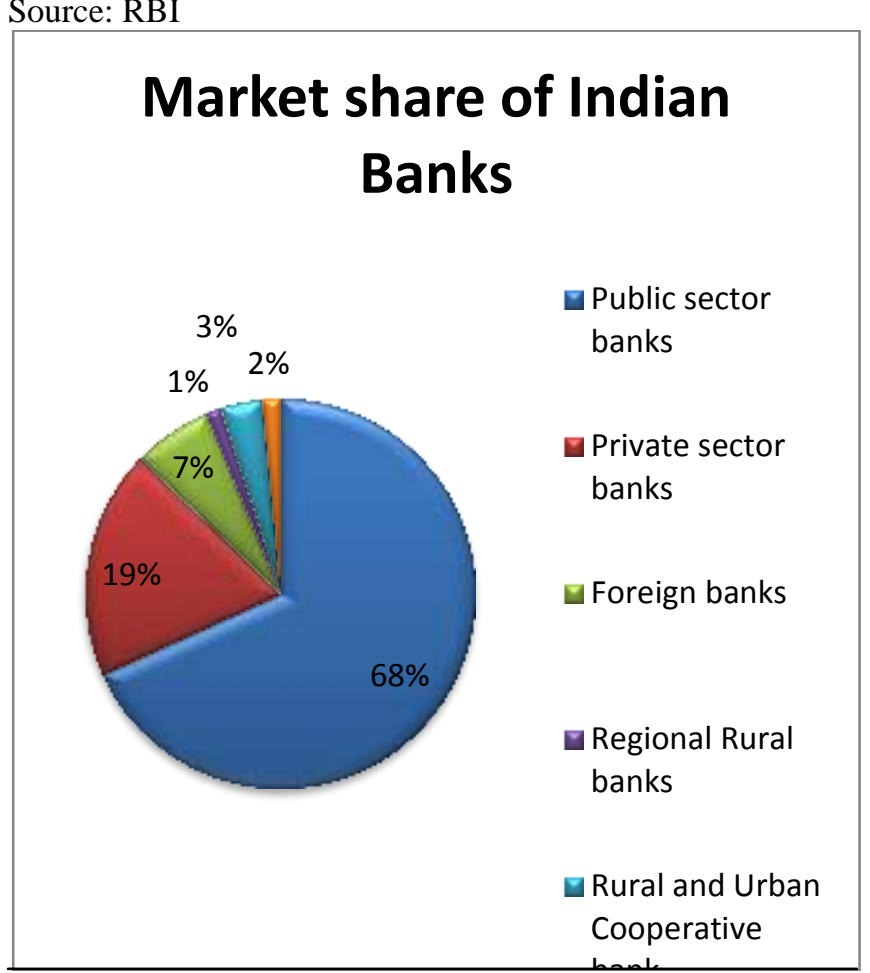

Macroeconomic concept

Macroeconomics is the study of entire economy of a nation. Economists assess the accomplishment of an economy's overall performance by studying certain macroeconomic variables. It deals with cyclical trends in gross domestic product, price level, exchange rate, interest rates, money supply, budget deficit and unemployment etc... Till the 1930s microeconomic and macroeconomic behavior were not considered separate. The representatives of Classical thoughts were Adam Smith with his publication "The Wealth of Nations" in 1776 along with David Recardo(1772-1823), Thomas Robert Malthus(1766-1834) and John Stuart Mill (1806-1873). Classical economists believed that market itself would adjust with any turbulence via automatic interaction of price flexibility. After the great depression of 1929 the British economist John Maynard Keynes in 1970 criticized the classical view and proposed a macroeconomic view towards economic problems.

\section{Financial Performance:}

Financial performance of any organization is proper utilization of its financial resources to generate revenue. To achieve this it is generally relied upon comparison between individual financial variables with other industry benchmarks and other macro economic variables. Individual items can be daily operational activities, operation cash flows, operating income, earning per share, yield in sales, profit on investment(ROI), return on equity(ROE) and return on overall assets (ROA) and stock prices etc.(Maria et al.,2002,2004,2007).

Measure of Bank's financial Performance in the study: Profit earning is the ultimate goal of every commercial bank. Various measures of financial performance are: Return on Asset, Return on Equity and Net Interest Margin, NPA to gross loans, Capital adequacy ratios are the major ones (Murthy and Sree, 2003; Alexandru, 2008).

\section{Return on Asset (ROA)}

ROA is the major ratio that presents the profitability position of a bank. It is calculated as a ratio of Income to its total asset (Khrawish, 2011). It also indicates the ability of the bank management. Banks generate income by utilizing company assets at their disposal. In other words, it shows how banking sector is efficiently earning with the proper utilization of its assets. Wen (2010) stated that a higher ROA indicates that the company is more efficient in using its resources. In the present study we have measured the financial performance in terms of ROA.

ROA $=\frac{\text { Net Income }}{\text { Total Assets }}$

ROA is calculated as a percentage of net income to total assets, and higher the ratio, the more efficient a company's management is considered to manage its balance sheet assets to generate profits.

\section{Macroeconomic variables and Financial Performance of Indian banks:}

Macroeconomic circumstances and interventions adopted by any government \& its central bank can stimulate profitability of banks. To monitor the financial stability central bank focus on macroeconomic and various FSIs (Financial stability indicators).Therefore the performance of banks in any nation's economy play a significant role in its growth. Profitability, liquidity and risk measurement are some of the factors contributing to the performance of banks. In this 


\section{International Journal of Engineering Applied Sciences and Technology, 2019}

Vol. 4, Issue 3, ISSN No. 2455-2143, Pages 259-265

Published Online July 2019 in IJEAST (http://www.ijeast.com)

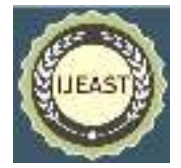

changing economic scenario it becomes very important to develop an economic model which creates relevant understanding of relationship between macroeconomic variables and financial performance of banks.

\section{LITERATURE REVIEW:}

Macro economic variables remains outside the control of any business organization and they include political, supplier, competitor, social, economic regulations. (Adidu and Olanye, 2006). Kwon and Shin (1999) argued that GDP, exchange rate, interest rate, inflation and market risk are very important macroeconomic variables. Some of these factors are output of an economy, unemployment, inflation, savings and investment etc.... These factors are major performance driver of an economy and are closely examined by each government (Khalid et al., 2012). GDP, Exchange rate, $\mathrm{CPI}$, interest rates, corporate tax, stock market index and other monetary regulations were continuously utilized to judge the macroeconomic indicators. (Mankiw \& Ball, 2010; Broadstock et al., 2011; World Bank Group, 2015)

Brinson et al (2009) explained macro economic variables as those variables that are relevant to a nationwide economy and affect the overall region rather than a few selected individuals. The study indentified major variables such as inflation, gross domestic product (GDP), currency exchange rate, interest rates, legal environment and risk of regulatory framework. Sharma and Singh (2011) stated that most of the firms while taking their financial decision over a longer period of time generally consider stability and favorability of macroeconomic variables.

Financial performance analysis is a process which identifies the financial and operational variables of an organization. It focuses on accounting and financial statements to analyze its efficiency and proficiency of a firm. Bhunia et al., 2011 stated that it reflects the financial records and different reports to control over its profitability and liquidity in a rational way to increase its market value. Tarawneh (2006) characterized the commercial banks in Oman in cohesive categories based on their financial performance which was analyzed by financial ratios.

Ganesan (1998), Nayak (2001), Bhatia and Verma (1998), Sarkar et al. (1998), Thamkirati (1996), Amandeep (1993), Karunagaran and Benjamin (1989), Vashist (1987) and Shirai (2002) worked prominently to assess the impact of macroeconomic variables on the financial performance of different banking system. The main focus in these studies remained to analyze the profitability, liquidity, capital adequacy, risk and efficiency of commercial banks. These studies highlight the bank's concern for loan growth, deposit growth, efficiency ratios, capital ratios, return on assets, and return on equity and credit quality in the form of
NPAs. The empirical findings indicate a strong positive relationship of exchange rate, inflation rate and lending interest rate with ROA

Many research studies highlight that financial performance of a bank is influenced by inflation rate, exchange rate and lending interest rate (Lowe \& Rohling 1993; Calomiris 1997; kaufman 1998).

Athanasoglou et al., (2006) examined the impact different macroeconomic variables on ROA over the period 19982002. The results indicate that inflation has significant and positive impact on ROA. In this study it was also stated that GDP does not seem to effect significantly on ROA.

\section{OBJECTIVE OF THE STUDY}

1. To find out the impact of GDP on ROA.

2. To find out the impact of inflation rate on ROA

3. To find out the impact of exchange rate on ROA

4. To find out the impact of lending interest rate on ROA

\section{Research Methodology}

Type of Research: The study is empirical in nature and based on quantitative methods.

Research Design: The research design is descriptive cum exploratory.

Data collection: the study is primarily based on secondary data collected from various national and international sources from 2000 to 2017.

Sources of Data collection

a) Handbook of Indian Statistics, RBI available at

b) National Statistics portal available at https:// india.gov.in/

c) Federal Reserve bank of St. Louis Available at https://research.stlouisfed.org/info-services.html

d) Data from World Bank ( assessed through https:// data.worldbank.org/)

e) Indian Trading Economics assessed through http://www.tradingeconomics.com/india/gdpgrowth-annual

Model Specification: The equation specified for estimation is in the following functional form:

\section{Equation}

$$
\mathrm{ROA}=\mathrm{f}(\log \mathrm{GDP}, \log \text { LINF, } \log \mathrm{EXR}, \log \mathrm{LINTR})
$$

$\beta 0+\beta 1 \mathrm{LGDP}+\beta 2 \mathrm{LINF}+\beta 3 \mathrm{LEXR}+\beta 4 \operatorname{LINTR}+\varepsilon$.

Where: $\beta 0=$ Intercept; $\beta 1-\beta 4=$ Coefficients of the regressors as defined above; $\varepsilon=$ stochastic term.

Return on Asset has been taken as dependent variable and GDP rate, Inflation rate, Lending Interest rate and Exchange rate( Rupees in 1 US \$) has been taken in dependent variables. Log values of all the variable has been computed using E-views. 
International Journal of Engineering Applied Sciences and Technology, 2019

Vol. 4, Issue 3, ISSN No. 2455-2143, Pages 259-265

Published Online July 2019 in IJEAST (http://www.ijeast.com)

Test applied on data:

- Unit Root Test: In this study ADF test has been used to check whether the time series data is nonstationary and possesses a unit root.

- ARDL Model for Long- run and Short-run Relationship among Variables: The autoregressive distributed lag model is used to explain the short run and long run coefficient. In this model bound testing method is used on the basis of F-test. If the value F-statistic is greater than the upper bound critical value of bound test then the null hypothesis of no cointegration is rejected and it is interpreted that variables are cointegrated. The ARDL bound test is based on Wald-test (Fstatistics).

\section{Diagnostic test:}

- Serial correlation: Breusch- Godfrey Serial Correlation to check serial correlation

- Hetroscedasticity: Breusch-Pagan-Godfrey test is used to check the Heteroskedasticity in time series.

- Granger Causality Test to check the direction of causality between two variables.

- Cusum and Cusum square to test the long run stability of the parameters.

Data Analysis:

Table: 1 Result of the Augmented Dickey-Fuller test (ADF) Unit Root test

\begin{tabular}{|l|l|l|l|}
\hline Variable & Status & t- Statistic & P value* \\
\hline ROA & I(1) & $\mathbf{- 3 . 8 1 1 5 4 3}$ & $\mathbf{0 . 0 1 2 3}$ \\
\hline GDPR & I(0) & $\mathbf{- 3 . 2 2 8 8 7 6}$ & $\mathbf{0 . 0 3 5 9}$ \\
\hline INFLR & I(1) & $\mathbf{- 3 . 0 6 6 2 9 8}$ & $\mathbf{0 . 0 4 9 9}$ \\
\hline EXR & I(1) & $\mathbf{- 2 . 8 5 8 0 3 6}$ & $\mathbf{0 . 0 0 7 3}$ \\
\hline LINTR & I(1) & $\mathbf{- 3 . 8 9 3 0 1 2}$ & $\mathbf{0 . 0 1 0 5}$ \\
\hline
\end{tabular}

(Calculated by author)

The above table represents the unit root test results. ROA (Return on Assets), INFLR (Inflation Rate), EXR (Exchange Rate), LINTR (Lending Interest Rate) is stationary at first Difference. GDPR is Stationary at level.

Table: 2 Result of Descriptive Statistics

\begin{tabular}{|l|l|l|l|l|l|}
\hline Values & ROA & GDPR & INFLR & EXR & LINTR \\
\hline Mean & .869063 & 6.938889 & 6.455556 & 50.90116 & 11.03056 \\
\hline Median & 0.979550 & 6.850000 & 5.700000 & 46.90540 & 10.83500 \\
\hline Maximum & 1.315760 & 10.30000 & 11.00000 & 67.15720 & 13.31000 \\
\hline Minimum & 0.307544 & 3.900000 & 3.600000 & 41.17740 & 8.330000 \\
\hline Std. Dev. & 0.271465 & 2.056879 & 2.561990 & 8.378614 & 1.269847 \\
\hline
\end{tabular}

\begin{tabular}{|l|l|l|l|l|l|}
\hline Skewness & - & - & 0.4784032 & 0.853867 & - \\
\hline Kurtosis & 2.394826 & 1.869839 & 1.642411 & 2.195066 & 2.600603 \\
\hline $\begin{array}{l}\text { Jarque- } \\
\text { Bera }\end{array}$ & 1.270956 & 0.958407 & 2.085146 & 2.673203 & 0.120263 \\
\hline Probability & 0.529682 & 0.619276 & 0.352543 & 0.262737 & 0.941641 \\
\hline Sum & 15.64313 & 124.9000 & 116.2000 & 916.2208 & 198.5500 \\
\hline $\begin{array}{l}\text { Sum Sq. } \\
\text { dev }\end{array}$ & 1.252784 & 71.92278 & 111.5844 & 1193.420 & 27.41269 \\
\hline
\end{tabular}

(Calculated by Author)

Table 2 represents results of the descriptive statistics of yearly data of Return on assets, GDP rate, Inflation rate and Lending interest rate.

Table: 3 Regression results of macroeconomic variable and ROA

Dependent Variable: LROA

Method: Least Squares

Date:03/15/19 Time:02:53

Sample: 20002017

Included observations: 18

\begin{tabular}{ccccc}
\hline \hline Variable & Coefficient & Std. Error & t-Statistic & Prob. \\
\hline \hline LGDPR & 0.312489 & 0.217680 & 1.435542 & 0.1731 \\
LINFLR & 0.404021 & 0.175186 & 2.306234 & 0.0369 \\
LEXR & -0.904775 & 0.261312 & -3.462437 & 0.0038 \\
LLINTR & 0.843899 & 0.385966 & 2.186462 & 0.0463
\end{tabular}

R-squared $=0.855260$, adjusted R-squared $=0.755260, F$ statistic $=10.02939$, Durbin - Watson 0stat $=2.190118$, Ramsey RESET test $=\mathbf{0 . 5 0 8 9 6 5}(0.730263)$

Table 3 shows the regression result of $\log$ values of ROA as dependent variable and log values of GDP, Inflation rate, Exchange rate and Lending as independent variables. The test result indicates that P-value of LINFR is 0.0369, LEXR stands at .0038 and LLINTR is 0.0463 which is less that $5 \%$ hence all these variables are significant variables. LGDPR Pvalue is 0.1731 which is more than 5\% so LGDP is not significant variable for defining LROA. R-squared is 0.855260 which defines that all these four variables together bring $85.52 \%$ variation in ROA.

Regression results indicate that there is positive relationship between LGDPR and LROA. If GDP on a country increases it brings overall growth in an economy, more production, more consumption, more demand for business and consumers' credit and ultimately more returns for banks. 


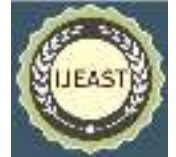

The result shows that $1 \%$ change in GDP increases ROA by $0.31 \%$. There is positive correlation between ROA and inflation rate if inflation rate will rise then prices of productions goods and consumables goods will rise so there will be more demand for credit thus return on bank assets will also increase. Regression results shows that $1 \%$ increase in inflation will bring $0.40 \%$ change in ROA. There is negative relationship between exchange rate and return on assets. Exchange rate has been defined as one Dollar in to rupee. If value of dollar will decrease then banks will have to pay less to purchase it, and all interest payments in terms of dollar will be cheap. Thus return on assets will increase. This will again increase the return on assets of banks. There is positive relationship between lending interest rate and Return on assets. Increase in lending rate will increase interest income from loans and naturally ROA will increase, $1 \%$ change in Lending interest rate will result $0.84 \%$ change in return on assets

Table: 4 Serial correlation test result

Breusch-Godfrey Serial Correlation LM Test:

Null hypothesis: No serial correlation at up to 2 lags

\begin{tabular}{llll}
\hline \hline F-statistic & & & \\
Obs ${ }^{*}$ R-squared & 2.226305 & Prob. F(2,11) & 0.1542 \\
\hline \hline
\end{tabular}

$\begin{array}{lll}\text { Log likelihood } & 12.13663 & \text { Hannan-Quin } \\ \text { F-statistic } & 0.742102 & \text { Durbin-Watsc } \\ \text { Prob(F-statistic) } & 0.627524 & \end{array}$

The above table shows the Breusch- Godfrey Serial correlation LM test which indicates that corresponding $\mathrm{P}$ value of Chi-Square is 0.0748 which is more than $5 \%$ hence we cannot reject the null hypothesis and we will accept the null. Null hypothesis is that there is no serial correlation between residual which is desirable for good fit of the model.

Table: 5 Heteroskedasticity testing results

Hēeroskedasticity Test: Breusch-Pagan-Godfrey

Null hypothesis: Homoskedasticity

\begin{tabular}{|c|c|c|c|}
\hline F-statistic & 0.270903 & Prob. $F(4,13)$ & $0.8 s$ \\
\hline Obs*R-squared & 1.384946 & Prob. Chi-Square(4) & 0.8 \\
\hline Scaled explained SS & 0.613036 & Prob. Chi-Square(4) & 0.96 \\
\hline Log likelihood & 39.65585 & Hannan-Quinn criter. & -3.8165 \\
\hline F-statistic & 0.270903 & Durbin-Watson stat & 2.5202 \\
\hline Prob(F-statistic) & 0.891489 & & \\
\hline
\end{tabular}

Residuals are homoskedastic because corresponding Prob (F-Statistic) is more than 5\%. We cannot reject the null hypothesis and we will accept it which is desirable. Null hypothesis is that the residuals are homoskedastic. Again this is good fit for the model.

\section{Graph 1: Normal Probability Distribution graph of residuals}

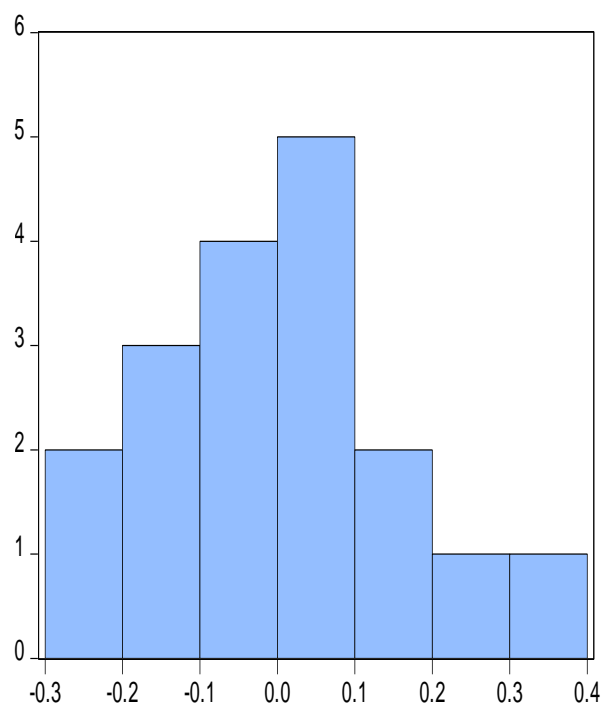

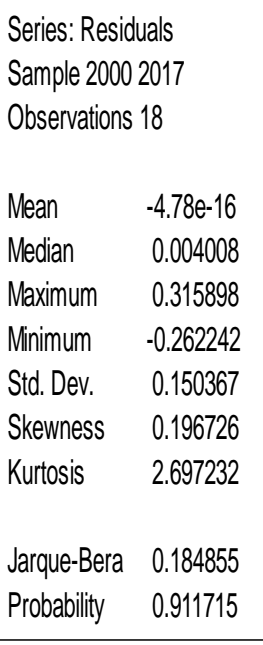

Residuals are normally distributed as Jarque-Bera test statistic corresponding probability is 18.48 which is more than $5 \%$. So we can not reject the null hypothesis. Null hypothesis is that residuals are normally distributed so we will accept it. This is again a desirable condition for good fit of the model.

Figure 1: Plot of Cumulative Sum of Recursive Residuals

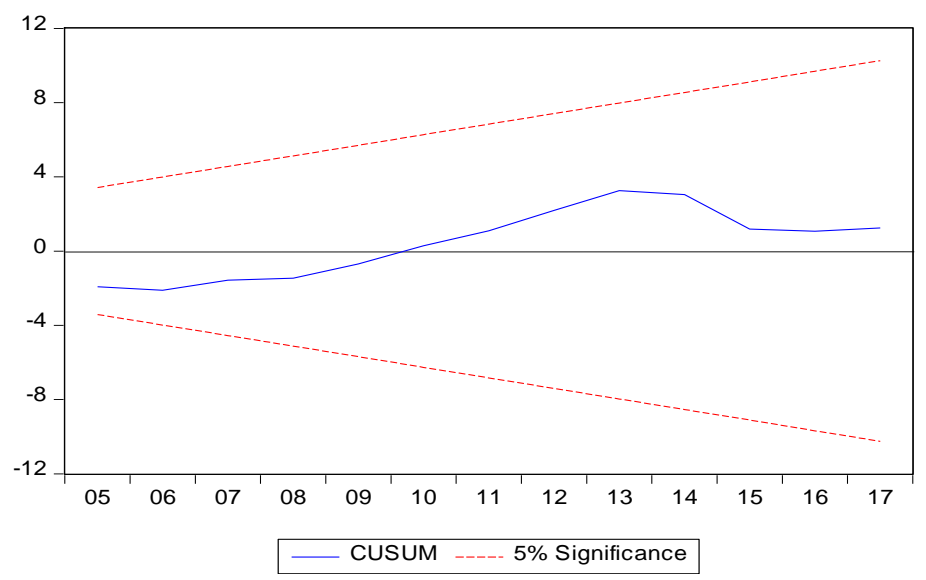

The above graph represents the CUSUM test result for residuals. As all the recursive residuals are lying within the critical bound at 5\% level of significance. Which is good sign for residuals representation and it is significant at $5 \%$ level. 


\section{International Journal of Engineering Applied Sciences and Technology, 2019}

Vol. 4, Issue 3, ISSN No. 2455-2143, Pages 259-265

Published Online July 2019 in IJEAST (http://www.ijeast.com)

\section{Figure2: Plot of Cumulative Sum of Recursive Residuals}

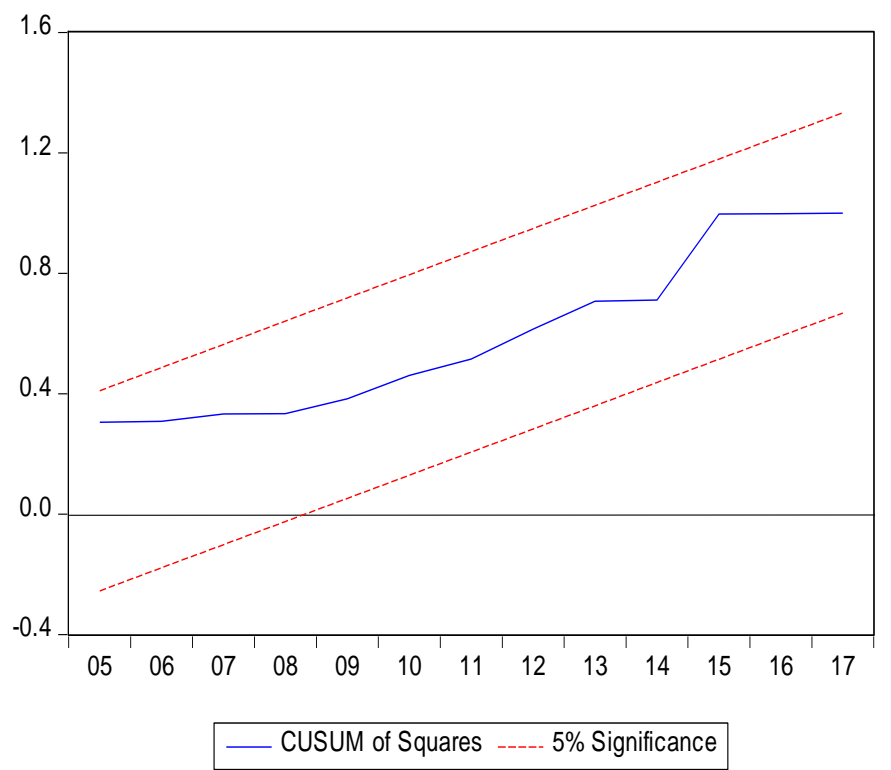

The above graph represents the CUSUMSQ test result for residuals. As all the recursive residuals are within the critical bound at 5\% level of significance. Which is good sign for residuals representation and it is significant at 5\% level.

Table 6. Johansen cointegration test

Unrestricted Cointegration Rank Test(Trace)

\begin{tabular}{|c|c|c|c|c|}
\hline $\begin{array}{l}\text { Hypothesized } \\
\text { No. ofCE(s) }\end{array}$ & Elgenvalue & $\begin{array}{l}\text { Trace } \\
\text { Statistic }\end{array}$ & $\begin{array}{c}0.05 \\
\text { Critical Value }\end{array}$ & Prob.** \\
\hline None * & 0.970632 & 122.8639 & 69.81889 & 0.0000 \\
\hline Atmost $1^{*}$ & 0.893979 & 66.41824 & 47.85613 & 0.0004 \\
\hline Atmost2 ${ }^{*}$ & 0.709255 & 30.51243 & 29.79707 & 0.0413 \\
\hline Atmost3 & 0.472354 & 10.74749 & 15.49471 & 0.2275 \\
\hline Atmost4 & 0.031870 & 0.518222 & 3.841466 & 0.4716 \\
\hline
\end{tabular}

Trace test indicates 3 cointegrating ean (s) at the 0.05 level

* denotes rejection of the hypothesis at the 0.05 level

The test indicates that there is long term relationship exist between all the variables. It is further stated that all the variables move together. Johansen cointegration test shows that there are three cointegration equations exist at 5\% level of significance.

Table 7: ARDL Bounds Test Value
ARDL Long Run Form and Bounds T... Dependent Variable: $\mathrm{D}(\mathrm{ROA})$

\begin{tabular}{lcccc} 
F-Bounds Test & \multicolumn{4}{c}{ Null Hypothesis: No levels relationship } \\
\hline \hline Test Statistic & Value & Signif. & $l(0)$ & I(1) \\
\hline \hline & \multicolumn{4}{c}{ Asymptotic: $n=1000$} \\
F-statistic & 6.585801 & $10 \%$ & 2.2 & 3.09 \\
$k$ & 4 & $5 \%$ & 2.56 & 3.49 \\
& & $2.5 \%$ & 2.88 & 3.87 \\
& & $1 \%$ & 3.29 & 4.37
\end{tabular}

The above result shows that value of F-statistics is more than the lower (2.56) and upper bond( 3.49) at 5\% level of significance which indicates that there is long term relationship among the variables at 5\% level of significance.

Table: 8 Pairwise Granger Causality Tests

\begin{tabular}{|c|c|c|}
\hline $\begin{array}{l}\text { LGDPR does not Granger Cause LROA } \\
\text { LROA does not Granger Cause LGDPR }\end{array}$ & 16 & $\begin{array}{l}0.23682 \\
0.38031\end{array}$ \\
\hline $\begin{array}{l}\text { LINFLR does not Granger Cause LROA } \\
\text { LROA does not Granger Cause LINFLR }\end{array}$ & 16 & $\begin{array}{l}1.96382 \\
2.36260\end{array}$ \\
\hline $\begin{array}{l}\text { LEXR does not Granger Cause LROA } \\
\text { LROAdoes not Granger Cause LEXR }\end{array}$ & 16 & $\begin{array}{l}6.69394 \\
1.05910\end{array}$ \\
\hline $\begin{array}{l}\text { LLINTR does not Granger Cause LROA } \\
\text { LROAdoes not Granger Cause LLINTR }\end{array}$ & 16 & $\begin{array}{l}0.93625 \\
0.35757\end{array}$ \\
\hline
\end{tabular}

\section{KEY FINDINGS OF THE STUDY}

The regression results indicate that P-value of LINFR is 0.0369 , LEXR stands at .0038 and LLINTR is 0.0463 which is less that $5 \%$ hence all these variables are significant variables. LGDPR P-value is 0.1731 which is more than $5 \%$ so LGDP is not significant variable for defining LROA. Rsquared is 0.855260 which defines that $85.52 \%$ variable in LROA is because of independent variable. LGDPR, LINFR, LLINTER are having positive relationship with LROA while LEXR is negatively associated with LROA. These results are in line with the studies of Kurt \& Huizinga(1999), Naceur(2003), Azami(2004), Wong(2006), Habibulla(2010) and Solovjova(2011).

The analysis of long run relationship between ROA and macro-economic variables is reported in the study with ARDL bound results and it affects the earning of the banks. 


\section{International Journal of Engineering Applied Sciences and Technology, 2019 \\ Vol. 4, Issue 3, ISSN No. 2455-2143, Pages 259-265}

Published Online July 2019 in IJEAST (http://www.ijeast.com)

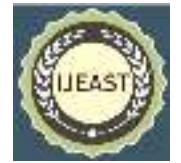

The results also indicate that inflation rate and exchange rate effect significantly to return on assets.

The study presents that the selected macroeconomic variables had an effect on the earning potential of Indian banking sector and it should be managed with continuous review on inflation rate and exchange rate fluctuations. Future forecasts should take into account regarding lending interest rate and GDP in particular as having the greatest influence on the direction taken by banks in India. Three out of Four of the variables (GDP, Inflation rate, Lending Interest rate) had a positive correlation with ROA though exchange rate had a negative correlation.

\section{CONCLUSION}

The conclusions drawn from the study are that increase in inflation rate, and lending interest rate increase the return on assets of the Banks. GDP growth rate is positively associated with ROA. Thus increase in GDP results growth in overall economy of a country. Due to such growth there will be growth in production, growth in demand for goods and services hence banks can earn more income through credit expansion. There is negative relationship between ROA and dollar appreciation in terms of rupee. If value of dollar will increase then Indian banks' return on assets wills decrease because to buy one dollar more rupees will have to pay and it will increase interest payments of banks on loans taken in dollar. Banks should use various hedging contracts to control the interest rate risk, currency risk and liquidity risk. For better management perspective banks need to implement functioning with monetary policies and risk analysis should be done on regular basis to track the fluctuations of the macroeconomic variables. Results of Pairwise Granger causality model shows that exchange rate granger cause the return on assets and there is existence of the directional relationship between exchange rate and return on assets of Indian banks so again exchange rate fluctuations should be considered to manage profitability of banks.

\section{REFERENCES}

1. Adidu A., and Olanye A. (2006). Basic Small Business Entrepreneurship- A Modern Approach, Royal Pace Publisher, Agbor, (pp. 1-10).

2. Alper D., and Anbar A. (2011). Bank Specific and Macroeconomic Determinants

of Commercial Bank Profitability: Empirical Evidence from Turkey. Business and Economics Research Journal Volume 2, (pp. 139-152).

3. Tamimi H. (2010). Factors Influencing Performance of the UAE Islamic and Conventional National Banks, Global Journal of Business Research, (pp. 1-9).
4. Angbazo L. (1997). Commercial Bank Interest Margins, Default Risk, Interest-rate Risk, and Off-balance Sheet Banking. Journal of Banking and Finance, (pp 55-87).

5. Bhunia A. and Roy G. (2011). Financial performance analysis: A case study. Current Research Journal of Social Sciences,(pp. 269-275).

6. Dietrich A., and Wanzenried G. (2009). What Determines the Profitability of Commercial Banks? New Evidence from Switzerland. 12th Conference of the Swiss Society for Financial Market Researches, Geneva.

7. Demirgüç-Kunt, A., \&Detragiache, E. (1998). The Determinants of Banking Crises: Evidence from Developed and Developing Countries. International Monetary Fund, 45(1)

8. Guru BK., Staunton, J., and Balashanmugam B. (1999). Determinants of Commercial Bank Profitability in Malaysia. 12th Annual Finance and Banking Conference,

Sidney, (pp. 1-22).

9. Issah M., and Antwi S. (2017). Role of macroeconomic variables on firms' performance: Evidence from the UK. Cogent Economics \& Finance (2017), 5: 1405581.

10. Kwon S., \& Shin S. (1999). Cointegration and causality between macroeconomic variables and stock market returns. Global Finance Journal, (pp. 71-81).

11. Murthy Y., and Sree R. (2003). A Study on Financial Ratios of major Commercial Banks, Research Studies, College of Banking \& Financial Studies, Sultanate of Oman.

12. Mirzaei, A. (2013). Bank performance during the financial crisis 2007-2010. International Journal of Business and Economics, 12(1), 27-44

13. Naceur, S. B. (2003). The Determinants of the Tunisian Banking Industry Profitability: Panel Evidence. UniversiteLibre de Tunis Working Papers.

14. Noman M., and Chowdhury M., Chowdhury, J., Kabir M., \& Pervin S. (2015). The effect of bank specific and macroeconomic determinants of banking profitability: a study on Bangladesh. International Journal of Business and Management, 10(6), (pp. 287).

15. Obamuyi, M. (2013). Determinants of bank's profitability in a developing economy: evidence from Nigeria. Organizations and Markets in Emerging Economies, 4(2), (pp. 97-109).

16. Petria, N., Capraru, B., \& Ihnatov, I. (2015). Determinants of banks profitability: evidence from EU 27 banking systems. Procedia Economics and Finance, 20, 518-524.

17. Sharma E., and Mani, M. (2012). Impact of Macroeconomic and financial market indicator on the banking sector: some evidence from India. IJRFM, 2(2), (pp. 2231-5985). 